\title{
Student Science Teachers' Ideas of the Digestive System
}

\author{
Osman Cardak \\ Correspondence: Osman Cardak, Necmettin Erbakan University, Ahmet Kelesoglu Faculty of Education, Konya, Turkey
}

Received: June 29, 2015 Accepted: July 13, 2015 Online Published: July 20, 2015

doi:10.11114/jets.v3i5.912

URL: http://dx.doi.org/10.11114/jets.v3i5.912

\begin{abstract}
The aim of this research is to reveal the levels of understanding of student science teachers regarding the digestive system. In this research, 116 student science teachers were tested by applying the drawing method. Upon the analysis of the drawings they made, it was found that some of them had misconceptions such as 'the organs of the digestive system have no relationships with each other' and 'it is an open-ended structure by which oral nutrients arrive at the stomach'. Additionally, it was concluded that some of them had insufficient knowledge. The importance of the findings was analysed in detail in the light of literature information. Suggestions for how to eliminate these problems were provided.
\end{abstract}

Keywords: digestive system, student's ideas, drawing method

\section{Introduction}

Some techniques are used in order to present the conceptual understandings and misconceptions of the students. Open-ended questions (Eisen \& Stavy, 1988), two-tier diagnostic tests (Haslam \& Treagust, 1987), interviews (Abdullah \& Scaife, 1997), concept maps (Novak \& Gowin, 1984), word association tests (Bahar, Johnstone \& Sutcliffe, 1999), and drawings (Prokop \& Fančovičova, 2006) may be given as examples of these techniques. Using drawings to access students' thinking has been a feature of educational research. Students can present a broad spectrum of ideas through drawings (Rennie \& Jarvis, 1995). This is in contrast to what is exposed by standard written texts, where students can repeat what they learned in class without revealing their misconceptions (Scherz \& Oren, 2006). Students' drawings are a useful means to present the misconceptions and conceptual understandings of the students in studies in the field of science (Dikmenli, 2010; Cardak, 2009; Bahar, Ozel, Prokop \& Usak, 2008; Kose, 2008; Prokop \& Fanèovièová, 2006; Ben-Zvi Assaraf \& Orion, 2005). Besides their benefits, these techniques can also have some disadvantages (Driver \& Erickson, 1983). As a technique for exploring ideas, drawing taps holistic understanding and prevents students from feeling constrained by attempting to match their knowledge with that of the researcher (White \& Gunstone, 2000). Therefore, science researchers use the drawing technique in order to reveal the understandings of students. On the other hand, as in every technique, drawing techniques can also have disadvantages as well as advantages. Strommen (1995) found that children's drawings of forests yielded less information than interviews. In his research, students tended to draw multiples of a single type of animal or plant, rather than different species. This would show that drawings are of limited value in detecting children's ideas about species diversity (Dove, Everett \& Preece, 1999).

In order to reveal the understandings of students, several researchers used children's drawings to examine their ideas about cell division (Dikmenli, 2010), digestive system (Gungor \& Ozgur, 2009), water cycle (Cardak, 2009), heart (Bahar, Ozel, Prokop \& Usak, 2008), the internal structure of animals (Prokop, Prokop, Tunnicliffe \& Diran, 2007), and endangered species (Erdogan \& Erentay, 2007).

In his study on children aged 4-16 about the functions of the human body, Gellert (1962) determined that the students had the misconception that 'the heart is used for breathing'. Prokop and Fančovičova (2006) also expressed that a maximum of $47.4 \%$ of prospective primary school teachers had misconceptions about the function of the heart such as 'heart beating prolongs life'. In their study, Bahar et al (2008) presented that most of the science student teachers had insufficient knowledge as well as misconceptions about the inner structure of the heart.

Many studies on the digestive system identified the misconceptions of students (Gungor \& Ozgur, 2009; Çakıcı, 2005; Carvalho, Silva \& Clément, 2003; Banet \& Nünez, 1997; Nünez \& Banet, 1997).

In the studies carried out in several countries about the digestive system in human beings, misconceptions such as defining the digestive system as 'a pipe with two open ends', defining the stomach as 'a balloon with no relationship 
with the mouth, having neither an entrance nor an exit', and expressing the stomach as the most important organ of the digestive system, were given as epistemologically rooted misconceptions (Carvallo, Silva \& Clement, 2003). In the researches, such misconceptions were found in individuals with different cultures in different countries (Carvallo, Silva \& Clement, 2003).

In their study, Gungor and Ozgur (2009) presented that the students established an incorrect relationship between the digestive system and the urinary system. From the drawings of the students, it was seen that the relationship that they established between the digestive and urinary systems was not a relationship which took place through the circulation system but a relationship in the form of direct connections between the digestive and urinary organs.

In his study in 2005, Cakici researched the understanding levels of 283 students aged 10-11. The most significant finding was the children's conception of the digestive process as 'melting of foods' rather than 'breaking foods down'.

In the Turkish education system curriculum, the digestive system is taught in several lessons at elementary and high school. Additionally, university science student teachers learn about the digestive system in general biology lessons and some other lessons involving physiology.

This study aims to reveal the misconceptions of science student teachers regarding the digestive system. The results of the present study will provide several opinions to teachers about teaching methods they can use for teaching the digestive system and its structure. In this study, the drawing method was used to achieve the following aims: what are the knowledge levels regarding the digestive system of the student science teachers in this research? And what are the misconceptions of the science student teachers?

\section{Methods}

In this study, the university student science teachers' understandings about digestive system were researched with the data collection tool using drawing methods.

\subsection{Participants}

A total of 116 students participated in this study. They were all studying to become student science teachers at Faculty of Education in Necmettin Erbakan University in Turkey. The university student science teachers participated in this study voluntarily. The average age of the students was 21.8 years (range $=19-26)$. The majority of the students were female (95 of 116). Participants had previously studied the digestive system in General Biology 2, Human Anatomy and Physiology, Special Issues in Biology as a school subject during various semesters. The study was carried out in March 2015.

\subsection{Data Collection and Analysis}

The participating student science teachers were asked to draw an human digestive system on a blank piece of A4 paper. The drawing method was chosen to enable a deep, clear insight into the students' understanding (Rennie \& Jarvis, 1995). There is evidence that students' drawings may serve as a useful tool for probing their level of understanding of natural phenomena and for identifying the gap between students' misconceptions and scientific ideas (Reiss \& Tunnicliffe, 2001; Tunnicliffe \& Reiss, 1999). Student science teachers' answers to the drawing activity were analysed using a coding framework prepared by Kose (2008), and Reiss and Tunnicliffe (2001). Next, all the drawings were scored by the researcher. The drawings were evaluated by two different biology education specialists. The scoring results were compared; the differences in a few cases were opened for discussion and then a final decision about the scoring was made. The drawings were addressed as a whole, and analysed through a scoring method that took the units on the drawing into consideration. The units on the drawing, rather than drawing capability, were taken into consideration when assessing the drawings. Five levels of conceptual understanding were identified for this research: no drawing, non-representational drawings, drawings with misconceptions, partial drawings and comprehensive representation drawings. Details of the levels are as follows (Dikmenli, 2010; Kose, 2008):

Level 1: No Drawing: Student science teachers replied, 'I don't know,' or no response was given to the statement.

Level 2: Non-Representational Drawings: These drawings included identifiable elements of the digestive system. In addition, the answers, which included diagrams or formulations instead of the drawings, were evaluated in this category. This category is illustrated by examples in Figures 1.

Level 3: Drawings with Misconceptions: These types of drawings showed some degree of understanding of the digestive system, but also demonstrated some misconceptions; however, these were misconceptions held by scientists or stated in science texts. This category is illustrated in Figures $2 \mathrm{a}$ and $2 \mathrm{~b}$.

Level 4: Partial Drawings: The drawings in this category demonstrated partial understanding of the concepts. This category is illustrated in Figure 3.

Level 5: Comprehensive Representation Drawings: Drawings in this category were the most competent and realistic 
drawings of the digestive system. This category is illustrated in Figure 4.

\section{Results}

The conceptual understanding levels of the student teachers were classified as no drawing, non-representational drawings, drawings with misconceptions, partial drawings and comprehensive representation drawings. The ranking was inspired by previous work in the field (Bahar et al., 2008; Kose, 2008; Reiss \& Tunnicliffe, 2001; Dove et al., 1999), the knowledge about anatomy and physiology of the researchers and the outcomes regarding the digestive system mentioned in the Turkish biology/science curricula. For these categories, advantage was taken in classifying the answers of the science student teachers in Table 1. The results of the student science teachers according to the five levels are given in Table 1.

Table 1. Student science teachers' conceptual understanding of the digestive system

\begin{tabular}{llll}
\hline Level & Understanding & N(116) & \% \\
\hline Level 1 & $\begin{array}{l}\text { No drawing (students replied, 'I don't know' or no response was given to the statement) } \\
\text { Level } 2\end{array}$ & $\begin{array}{l}\text { Non-representational drawings (these drawings included identifiable elements of the } \\
\text { digestive system. This category is illustrated by examples in Figures 1) }\end{array}$ & 7.6 \\
Level 3 & $\begin{array}{l}\text { Drawings with misconceptions (these types of drawings showed some degree of } \\
\text { understanding of the digestive system, but also demonstrated some misconceptions; }\end{array}$ & 24 \\
& $\begin{array}{l}\text { however, these were misconceptions held by scientists or stated in science texts. This } \\
\text { category is illustrated in Figures 2a and 2b). }\end{array}$ & 20.7 \\
Level 4 & $\begin{array}{l}\text { Partial drawings (the drawings in this category demonstrated partial understanding of the } \\
\text { concepts. This category is illustrated in Figure 3). }\end{array}$ & 59 \\
Level 5 & $\begin{array}{l}\text { Comprehensive representation drawings (drawings in this category were the most } \\
\text { competent and realistic drawings of the digestive system. This category is illustrated in }\end{array}$ & 23 \\
Total & Figure 4). & $\mathbf{1 1 6}$ & 10.8 \\
\hline
\end{tabular}

As can be seen in Table 1, the most dominant category was Level 4, partial drawings, where students had a partial understanding. This accounted for $50.9 \%$ of the student teachers. The category in which students showed a full understanding accounted for $19.8 \%$. The student teachers had very few non-representational drawings $(6 \%)$. This shows that student teachers partially know the organs of the digestive system. Additionally, it was clearly presented that they had misconceptions and lack of knowledge in some drawings (20.7\%). The percentage of the student teachers with misconceptions was of importance. All these results demonstrate that student teachers had a lack of knowledge in relation to the digestive system.

Table 2. The most frequent structure drawn by student science teachers

\begin{tabular}{lll}
\hline & N(116) & $\begin{array}{c}\text { \%o } \\
\text { total }\end{array}$ \\
\hline Stomach & 102 & 88.0 \\
Mouth & 99 & 85.3 \\
Pharynx & 76 & 65.5 \\
Oesophagus & 75 & 64.7 \\
Small intestine & 75 & 64.7 \\
Large intestine & 72 & 62.1 \\
Anus & 33 & 28.4 \\
Liver & 27 & 23.3 \\
Pancreas & 26 & 22.4 \\
Gall bladder & 15 & 12.9 \\
Teeth & 13 & 11.2 \\
Throat & 5 & 4.3 \\
Windpipe & 5 & 4.3 \\
Tongue & 3 & 2.6 \\
Heart & 3 & 2.6 \\
Duodenum & 3 & 2.6 \\
Lungs & 1 & 0.9 \\
Eyes & 1 & 0.9 \\
Brain & 1 & 0,9 \\
\hline
\end{tabular}

The drawings were analysed one by one, and the frequency of the organs which were drawn by the student teachers in relation to the digestive system is shown in Table 2. In the drawings, the organs with roles in digestion such as stomach, mouth, pharynx, oesophagus, small intestine and large intestine were determined to be more. The organs with roles in the digestive system such as liver, pancreas and gall bladder were drawn less. The stomach was drawn by $88 \%$ of the students while $85.3 \%$ of them drew the mouth. The anus was drawn by $28.4 \%$. The lungs, eyes and brain, none of which have any association with the digestive system, were drawn by $1 \%$ of the students. 


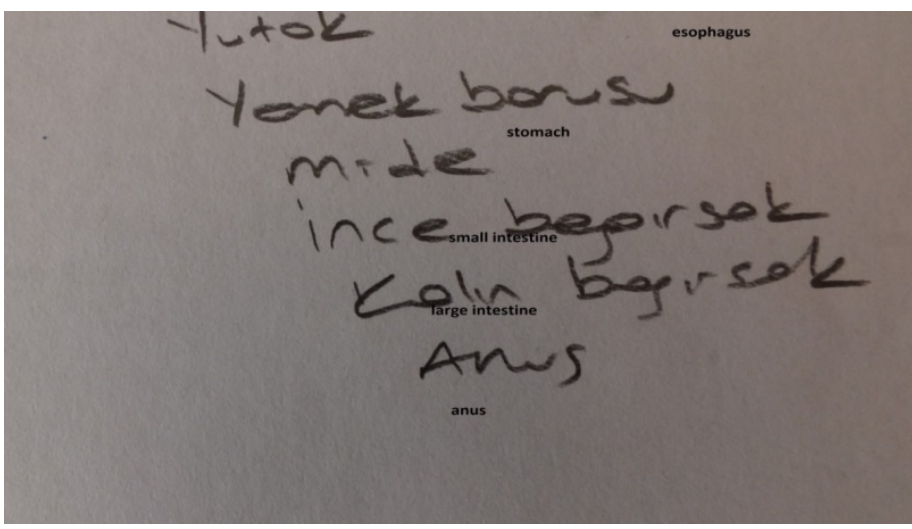

Figure 1. Example of Level 2 (non-representational drawing)

Figure 1 shows one drawing of student science teachers at the non-representational Level 2. Figures $2 \mathrm{a}$ and $2 \mathrm{~b}$ show two examples at drawing Level 3 (understanding with misconceptions). As can be seen from Figures $2 \mathrm{a}$ and $2 \mathrm{~b}$, student teachers thought the mouth did not have any duties in digestion. The student teacher did not draw the mouth in the digestive system in either of the figures. In Figure 2a, the student teacher also had misconceptions about the location of the stomach and other digestive organs. The student teacher also drew some organs which did not have any association with each other. The student teacher drew both small intestine and large intestine in the stomach. They did not establish any connection between the elements of digestion. The locations of the gall bladder, liver and pancreas were also incorrect. In Figure 3, there was partial drawing (Level 4). The student teacher did not draw the pharynx and the anus which are the most important organs with roles in the digestive system (Figure 3). Figure 4 shows an example of drawings for the fifth category (comprehensive representation drawings with and without misconceptions). Figure 5 belongs to a student teacher who has the misconception of thinking the digestive system only consists of the stomach and the intestines and does not establish any connection between the organs (Figure 5).
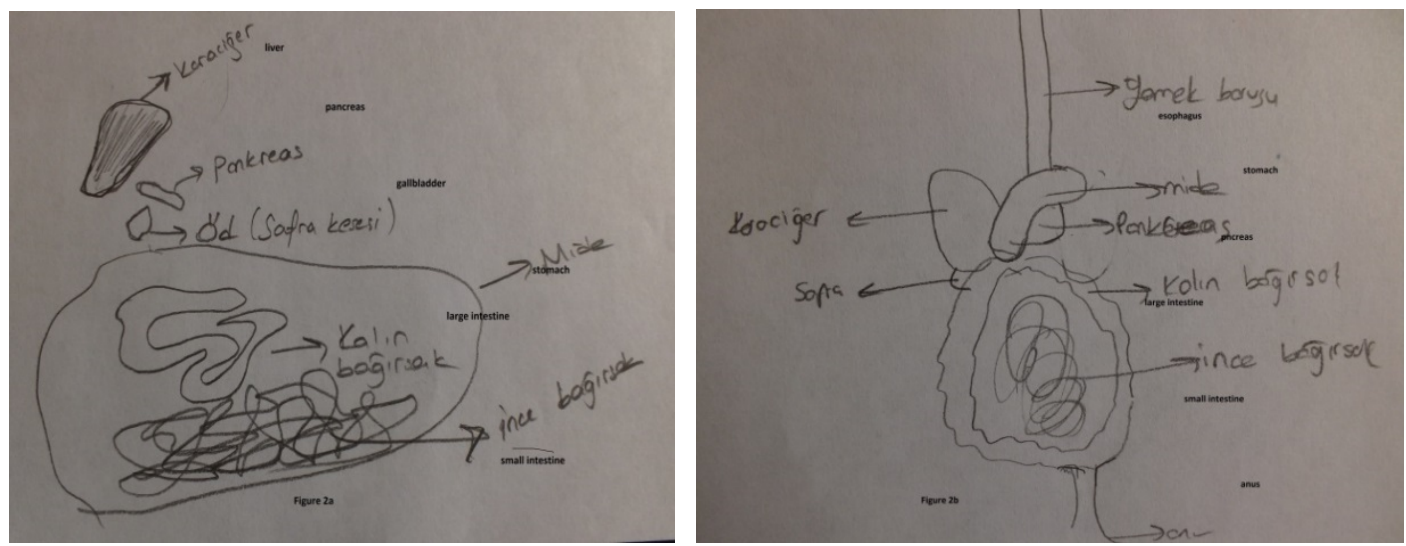

Figure 2a, 2b. Example of Level 3 (drawing with misconception)

In Figure 3, there was partial drawing (Level 4). The student teacher drew the organs such as mouth, oesophagus, stomach, liver, gall bladder, large intestine and small intestine but did not draw the pharynx and the anus (Figure 3). Figure 4 shows example of drawings for the fifth category (comprehensive representation drawings with and without misconceptions).

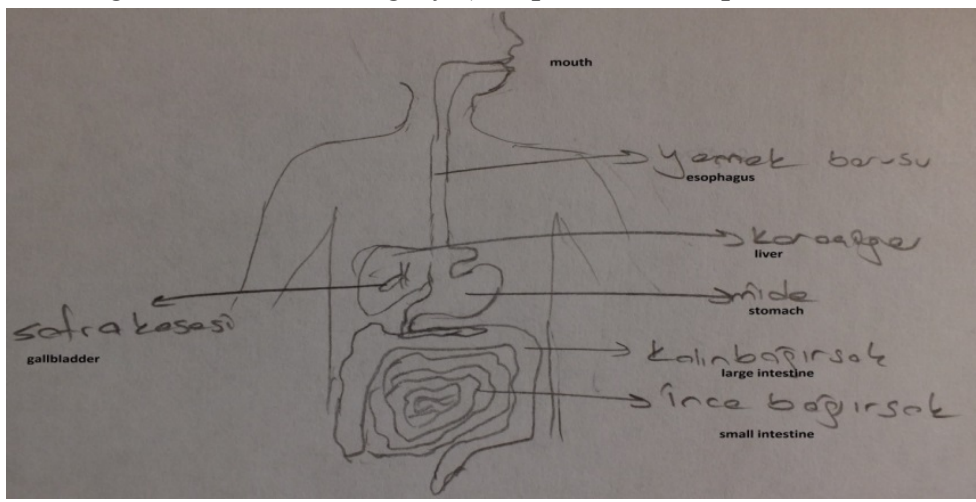

Figure 3. Examples of Level 4 (partial drawing) 


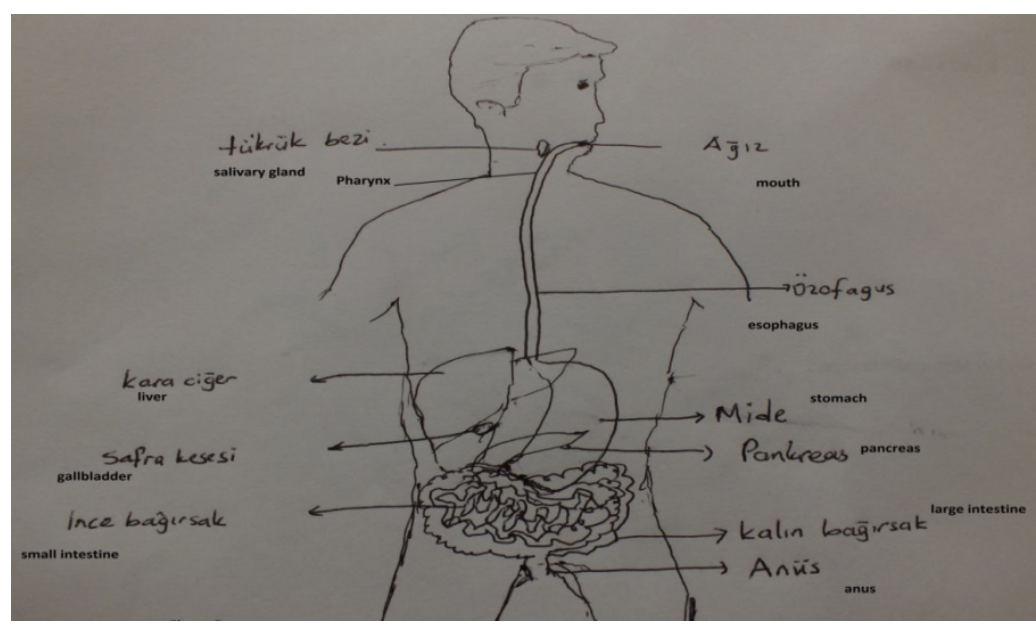

Figure 4. Examples of Level 5 (comprehensive representation drawing)

Figure 5 belongs to a student teacher who has the misconception in thinking the digestive system only consists of the stomach and the intestines, and does not establish connection between the organs. The student teacher drew the stomach and the intestine as two organs with no connections (Figure 5). In Figure 6, on the other hand, the student teacher showed that the nutrients which are taken orally arrived in the stomach in the shape of a bag. The student teacher had the misconception that the digestive system was a single open-ended structure which started in the mouth and ended in the stomach in the shape of a bag (Figure 6).

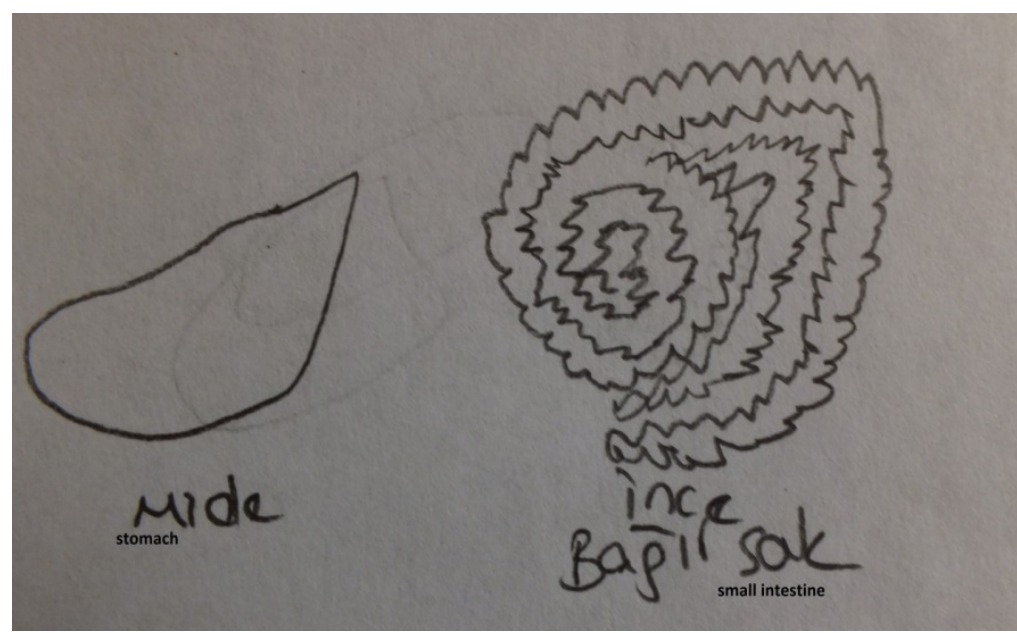

Figure 5. A drawing of misconception of digestive system (organs which do not have any associations with each other)

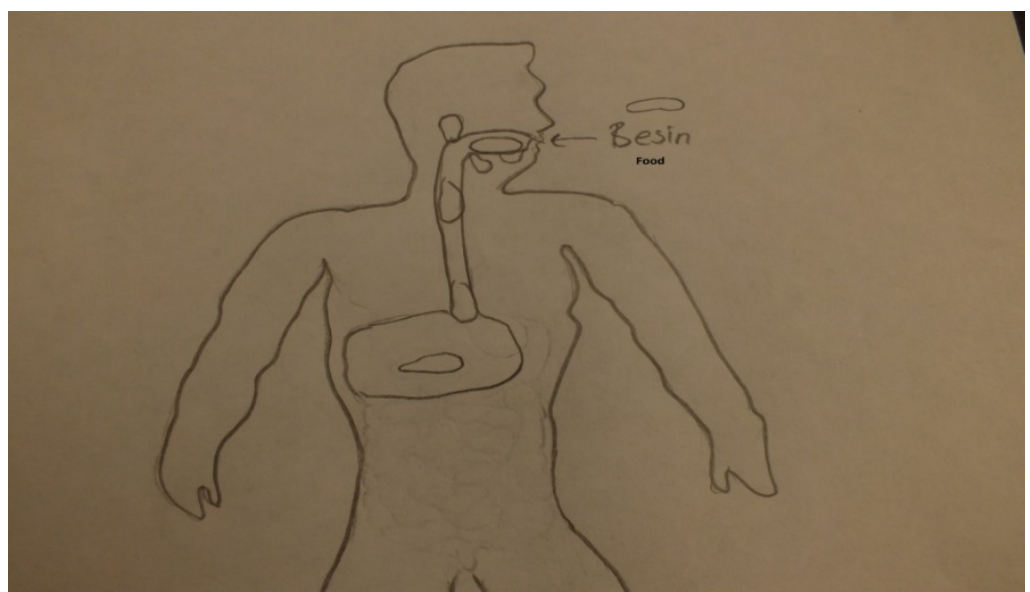

Figure 6. A drawing of misconception of digestive system (a single open-ended structure which starts in the mouth and ends in the stomach in the shape of a bag). 


\section{Discussion and implications}

The purpose of this study was to determine the opinions of science student teachers about the digestive system by using the drawing technique. All results of this study show that science student teachers have a lack of knowledge or misconceptions in relation to the digestive system. One of the misconceptions that the student teachers have was that they drew the digestive system as a single open-ended structure which starts in the mouth and ends in the stomach in the shape of a bag. Some student teachers drew the digestive system as the organs with no associations with each other. These errors were similar to the results of the research made by Gungor \& Ozgur (2009) with fifth-grade students at elementary school.

As we have already mentioned previously, the drawing method not only has some advantages but also disadvantages (Dove et al., 1999). In this research, in spite of the fact that student science teachers were informed about the drawing method and a practical session was applied, it could seem that the limitations of the method might have caused difficulties since the drawing of the digestive system may require more skills than drawing an ordinary concept.

The reason that the student teachers have all these misconceptions and lack of knowledge could be the teaching methods and techniques used, for misconceptions are quite resistant to change (Bahar, 2003; Pfundt \& Duit, 2004).

Wandersee, Mintzes and Novak (1994) state that misconceptions cannot be removed by traditional teaching strategies. In the majority of the schools and universities in Turkey, teachers and lecturers use mainly teacher-centred strategies that promote memorization and reproduction of the knowledge on the day of examination, where the multiple-choice format is mainly used (Bahar et al., 2008; Bahar, 2003).

In order to avoid future misconceptions and change the existing misconceptions in terms of the digestive system, teaching strategies in should be used in which students are more active. Teaching strategies including students doing and experiencing will be effective in preventing and changing the misconceptions. In order to change the misconceptions of the students, it is primarily necessary to determine those misconceptions. Furthermore, teaching technologies and virtual reality techniques are effective in teaching the digestive system topics and providing conceptual change. Furthermore, lack of knowledge and misconceptions about the digestive system can be removed by using the conceptual change texts together with conceptual teaching strategies, namely concept maps, concept networks, meaning analysis tables and concept cardboards. When we consider the science student teachers as the teachers of the future, it can be seen how important it is to ensure there are no future misconceptions and that any existing misconceptions are removed.

\section{References}

Abdullah, A., \& Scaife, J. (1997). Using interviews to assess children's understanding of science concepts. School Science Review, 78(285), 79-84.

Bahar, M. (2003). Misconceptions in Biology Education and Conceptual Change Strategies. Educational Sciences: Theory \& Practice, 3(1), 27-64.

Bahar, M., Johnstone, A. H., \& Sutcliffe, R. G. (1999). Investigation of students' cognitive structure in elementary genetics through word association tests. Journal of Biological Education, 33(3), 134-142. http://dx.doi.org/10.1080/00219266.1999.9655653

Bahar, M., Ozel, M., Prokop, P., \& Usak, M. (2008). Science student teachers' ideas of the heart. Journal of Baltic Science Education, 7(2), 78-85.

Banet, E., \& Nunez, F. (1997). Teaching and learning about human nutrition: A constructivist approach. International Journal of Science Education, 19(10), 1169-1194. http://dx.doi.org/10.1080/0950069970191005

Ben-Zvi Assaraf, O., \& Orion, N. (2005). Development of system thinking skills in the context of Earth system education. Research in Science Teaching, 42(5), 518-560. http://dx.doi.org/10.1002/tea.20061

Cakici, Y. (2005). Exploring Turkish upper primary level pupils' understanding of digestion. International Journal of Science Education, 27(1), 79-100. http://dx.doi.org/10.1080/0950069032000052036

Cardak, O. (2009). Science students' misconceptions of the water cycle according to their drawings. Journal of Applied Sciences, 9(5), 865-873. http://dx.doi.org/10.3923/jas.2009.865.873

Carvalho, G. S., Silva, R., \& Clément, P. (2003). Epistemological and didactical learning obstacles identified in Portuguese primary school pupils (Synopsis), Research and the Quality of Science Education. ESERA, Noordwijkerhout, CD.

Dikmenli, M. (2010). Misconceptions of cell division held by student teachers in biology: A drawing analysis. Scientific Research and Essay, 5(2), 235-247. 
Dove, J. E., Everett, L. A., \& Preece, P. F. W. (1999). Exploring a hydrological concept through children's drawings. International Journal of Science Education, 21(5), 485-497. http://dx.doi.org/10.1080/095006999290534

Eisen, Y., \& Stavy, R. (1988). Students' understanding of photo- synthesis. The AmericanBiology Teacher, 50, $209-212$.

Erdogan, M., \& Erentay, M. (2007). Children's perceptions on endangered species and threatened environments: results from unique and universal project. Proceedings of the 4th International Conference on Hands-on Science. Costa, M. F., Dorrio, B.V., Reis, R. (Eds.), University of Azores; Ponta Delgada, Portugal. 141-148.

Gellert, E. (1962). Children's conceptions of the content and functions of the human body. Genetic Psychology Monographs, 65, 293-405.

Gungor, B., \& Ozgur, S. (2009). Ilkögretim Beşinci Sınıf Ogrencilerinin Sindirim Sistemi Konusundaki Didaktik Kkkenli Kavram Yanılgılarının Nedenleri. Necatibey Faculty of Education Electronic Journal of Science and Mathematics Education, 3( 2), 149-177.

Haslam, F., \& Treagust, D. F. (1987). Diagnosing secondary students' misconceptions of photosynthesis and respiration in plants using a two-tier multiple-choice instrument. Journal of Biological Education, 21(3), 203-211. http://dx.doi.org/10.1080/00219266.1987.9654897

Kose, S. (2008). Diagnosing student misconceptions: Using drawings as a research method. World Applied Sciences Journal, 3(2), 283-293.

Novak, J. D., \& Gowin, D. B. (1984). Learning How to Learn. New York: Cambridge University Press. http://dx.doi.org/10.1017/CBO9781139173469

Nunez, F., \& Banet, E. (1997). Students' conceptual patterns of human nutrition. International Journal of Science Education, 19(5), 509-526. http://dx.doi.org/10.1080/0950069970190502

Pfundt, H., \& Duit, R. (2004). Bibliography: Students' Alternative Frameworks and Science Education. Kiel, Germany: University of Kiel Institute for Science Education.

Prokop, P., \& Fančovičova, J. (2006). Students' ideas about the human body: Do they really draw what they know? Journal of Baltic Science Education, 2(10), 86-95.

Prokop, P., Prokop, M., Tunnicliffe, S. D., \& Diran, C. (2007). Children's ideas of animals' internal structures. Journal of Biological Education, 41(2), 62-67. http://dx.doi.org/10.1080/00219266.2007.9656064

Reiss M. J., \& Tunnicliffe, S. D. (2001). Students' understandings of human organs and organ systems. Research in Science Education, 31, 383-399. http://dx.doi.org/10.1023/A:1013116228261

Rennie, L. J., \& Jarvis, T. (1995). Children's choice of drawings to communicate their ideas about technology. Research in Science Education, 25, 239-252. http://dx.doi.org/10.1007/BF02357399

Scherz, Z., \& Oren, M. (2006). How to change students' images of science and technology. Science Education, 90(6), 965-985. http://dx.doi.org/10.1002/sce.20159

Strommen, E. (1995). Lions and tigers and bears, Oh my! Children's conceptions of forests and their inhabitants. Journal of Research in Science Teaching, 32, 683-698. http://dx.doi.org/10.1002/tea.3660320704

Tunnicliffe, S. D., \& Reiss, M. J. (1999) Student's understanding about animal skeletons, International Journal of Science Education, 21(11), 1187-1200. http://dx.doi.org/10.1080/095006999290147

Wandersee, J. H., Mintzes, J. J., \& Novak, J. D. (1994). Research on alternative conceptions in science. In D. Gabel (Ed.), Handbook of Research on Science Teaching and Learning: A Project of the National Science Teachers Association, 177-210. New York: Macmillan.

White, R., \& Gunstone, R. (1992). Probing Understanding. London: Falmer Press. 